\title{
THE INFLUENCE OF CORPORATE DEBT FINANCING ON EARNINGS QUALITY
}

\author{
CHRISTINE LEONARDI \\ IRWANTO HANDOJO \\ Trisakti School of Management \\ irwanto@stietrisakti.ac.id
}

\begin{abstract}
The objective of this research is to obtain empirical evidence about the influences of different levels of debt (whole debt, low debt, and high debt), operating cycle, firm size, sales volatility, cash flows volatility, losses, cost of debt, and Z-score to earnings quality. The population in this research is non-financial companies excluding service sector listed in Indonesia Stock Exchange during 2007-2013. Samples are obtained through purposive sampling method with observation period from 2011 to 2013, which only 83 of listed non-financial companies excluding service sector in Indonesia Stock Exchange meet the sampling criteria, resulting 245 data available are taken as the samples. The result shows that debt and losses have influence on earnings quality. Directionally, low debt has positive influence and high debt has negative influence on earnings quality. Firm size has influence on earnings quality when it is regressed with whole debt. Meanwhile, it has no influence when it is regressed with low and high debt. Sales volatility, cash flows volatility, cost of debt and Z-score have no influence on earnings quality.
\end{abstract}

Keywords: $\quad$ Earnings Quality, Debt, Operating Cycle, Size, Sales Volatility, Cash Flows Volatility, Losses, Cost of Debt, Z-score.

\begin{abstract}
Abstrak: Tujuan penelitian adalah untuk mendapatkan bukti empiris tentang pengaruh berbagai tingkat hutang (seluruh hutang, hutang rendah, dan hutang tinggi), siklus operasi, ukuran perusahaan, volatilitas penjualan, volatilitas arus kas, kerugian, biaya hutang, dan Z-score terhadap kualitas laba. Populasi dalam penelitian adalah perusahaan non-keuangan tidak termasuk sektor jasa yang terdaftar di Bursa Efek Indonesia selama 2007-2013. Sampel diperoleh melalui metode purposive sampling dengan periode observasi 2011-2013, yang hanya 83 perusahaan non-keuangan yang terdaftar tidak termasuk sektor jasa di Bursa Efek Indonesia memenuhi kriteria sampel, sehingga 245 data yang tersedia diambil sebagai sampel. Hasilnya menunjukkan bahwa hutang dan kerugian memiliki pengaruh terhadap kualitas laba. Utang yang rendah memiliki pengaruh positif dan utang yang tinggi memiliki pengaruh negatif terhadap kualitas laba. Ukuran perusahaan memiliki pengaruh pada kualitas laba ketika regresi dengan seluruh hutang. Sementara itu, tidak memiliki pengaruh ketika mengalami kemunduran dengan hutang yang rendah dan tinggi. Volatilitas penjualan, volatilitas arus kas, biaya hutang dan skor-Z tidak memiliki pengaruh terhadap kualitas laba.
\end{abstract}

Kata kunci: Kualitas laba, hutang, siklus operasi, ukuran perusahaan, volatilitas penjualan, volatilitas arus kas, kerugian, biaya hutang, Z-score 


\section{INTRODUCTION}

As profitable organizations, companies need to sustain in a competitive, rapid technological change along with the development of business. In this condition, firms should have adequate financing, which can be obtained from different funding sources. One way to fulfill the needs is debt financing. Before granting any loan to a company, creditors need to know the solvency of the company. In assessing it, creditors need high quality information in the firms' financial statement. Sometimes, to convince the creditors, the company deliberately manipulates the financial statement to conceal its real financial condition. Therefore, the financial statement will not be fairly presented.

The capital structure of a company may consist of different debt levels, either low or high. These lead to contrary views about each influence on earnings quality. According to Ghosh and Moon (2010) as well as Valipour and Moradbeygi (2011), companies with low debt financing tend to report their earnings transparently because the risk of violating debt covenants is low. Therefore, managers are likely to present high-quality earnings in order to reduce the borrowing cost (Diamond, 1991 in Ghosh and Moon, 2010). In this case, low debt financing is expected to have positive influence on earnings quality.

Boulton et al. (2011), as cited in Sutopo (2012), stated that earnings quality in Indonesia is still lower than developed countries such as the United States and Australia. One of the most influencing factors of earnings quality is debt. The usage of corporate debt financing in Indonesia is increasing year by year, which consequently inflates the principal and interest payment. The higher the debt financing level, the higher the risk of violating debt covenants (Valipour and Moradbyegi, 2011). Consequently, creditors may increase the borrowing cost and ask for rapid payments. Therefore, companies tend to manage their earnings by using discretionary accruals to convince the creditors in granting loan (Sweeney, 1994). In this condition, high debt financing is expected to have negative influence on earnings quality (Ghosh and Moon, 2010).

The motivation of this research is to prove the contrast views about the influence of different levels of corporate financing on earnings quality in firms listed in Indonesia Stock Exchange. In addition, the objective of this research is to examine the relationship between variables and obtain the empirical evidence about the influence of debt (low debt, high debt), operating cycle, firm size, sales volatility, cash flow volatility, losses, cost of debt, and Z-score on earnings quality. The development of variable model for this research is a replication of the research made by Valipour and Moradbeygi (2011). The reason behind the replication is because earnings quality has not been a common topic in Indonesia, so there are only a few researches about this. The uniqueness of this research compared with the previous one is different research object and samples used (non-financial firms excluding service sector listed in Indonesia Stock Exchange while Valipour and Moradbeygi (2011) used nonfinancial firms excluding capital investment sector listed in Tehran Stock Exchange).

\section{Agency Theory}

Agency theory is a contract under which one or more persons (the principal) engage another person (agent) to perform some service on their behalf which involves delegating some decision-making authority to the agent. One issue in agency theory is conflict between debt holders and shareholders, where managers are assumed to act in the best interest of shareholders' or become a shareholder himself (Jensen and Meckling, 1976). When a firm chooses debt as majority for its capital, the owner-manager will have a strong incentive to engage in high return-high risk investments (Jensen and Meckling, 1976). Debt holders can limit the managerial behavior by including 
several covenants in the provisions of indenture which incur barriers on management's decisions such as dividends, future debt issues, and maintenance of working capital or certain financial ratio (Jensen and Meckling 1976).

\section{Information Asymmetry}

As agents, managers are more aware of internal information and prospects of the company in the future than the owners (shareholders). Therefore, the manager is responsible to provide information about the company's financial position to the owner. However, sometimes the information submitted is not fairly stated compared to the actual condition of the company. This condition is known as information asymmetry between management (agent) with the owner (principal), which can provide an opportunity for managers to manage the earnings (Mediaty, 2013).

Pagalung and Sudibdyo (2012) argued that one way to reduce the information asymmetry is by revealing the qualified information. Ball and Shivakumar (2008) stated that "public-company investors, lenders and other financial statement users are at greater "arm's length" than in a private company, and consequently demand higher quality reporting to resolve the information asymmetry". Chaney and Lewis (1995) in Linck et al. (2013) suggest that discretionary accruals can be used as a signal includes who show that when there is information asymmetry between investors and managers, the strategic management of reported earnings can reveal information about the firm.

\section{Earnings Quality}

Earnings quality is a major dimension of the financial reporting quality, as earnings constitute a premier source of firm-specific information (Francis et al., 2005). Furthermore, Dechow et al. (2010) stated that "higher quality earnings provide more information about the features of a firm's financial performance that are relevant to a specific decision made by a specific decision maker". When reported earnings help the users to take better decisions, then the quality of earnings is better. Obviously, the earnings quality is high when there isn't any earnings management (Valipour and Moradbeygi, 2011).

In relation with debt, Watts and Zimmerman (1990) stated that earnings play an important role in contracting being used in both debt covenants and compensation agreements. Furthermore, these uses may motivate managers manipulate financial disclosures for reasons such as avoiding the violation of debt covenants (DeAngelo et al., 1994 and Sweeney, 1994). This action reflects lower earnings quality since earnings quality is inversely related to earnings management (Ghosh and Moon, 2010; Kieso et al. 2011, 145-146).

\section{Debt}

Debt is an obligation that must be paid when it comes due. Debt includes all borrowing incurred by a firm, including bonds, and is repaid according to a fixed schedule of payment (Gitman and Zutter 2011, 266). Debt is as an example of pre-commitment or bonding device (Valipour and Moradbeygi, 2011). Debt contracts create an incentive for some corporate managers to manage earnings in order to avoid the violation of these contracts. Because debt affects managerial incentives and reporting choices, the linkages between debt and earnings quality depend on accruals quality (Ghosh and Moon, 2010).

$\mathrm{H}_{1} \quad$ : Debt has influence on earnings quality.

Debt holders demand higher quality information, especially earnings, to assess the continued creditworthiness of borrowers (Grossman and Hart, 1982; Jensen, 1986 in Ghosh and Moon, 2010). For low debt, companies have expected to cut fewer restrictions in order to reduce violating of debt obligations. Managers are also less likely to manipulate earnings to report the quality of earnings at low level, when the risk of violating 
commitment is low. Since debt reduces various agency conflicts, managers have few reasons to conceal the economic performance using their accounting discretion (Jensen, 1986; Stulz, 1990 in Ghosh and Moon, 2010). Thus, debt has a 'positive influence' on earnings quality through its effect on accruals.

$\mathrm{H}_{1 \mathrm{a}}$ Low debt has positive influence on earnings quality.

In contrast, a firm with high level of debt will have 'negative influence' on earnings quality. High levels of or changes in debt ratios may indicate high likelihood of violating debt covenants and accordingly strong incentives to overstate earnings in order to convince the creditors (Sweeney, 1994). This will lead the opportunistic managers to use accounting methods that reduce the likelihood of debt covenant violations (Watts and Zimmerman, 1990). Therefore, accounting numbers may not faithfully represent the future economic performance because of the aggressive use of accruals to manage earnings in an effort to avoid covenant violations (Sweeney, 1994; DeFond and Jiambalvo, 1994 in Ghosh and Moon, 2010). $\mathrm{H}_{1 b}$ High debt has negative influence on earnings quality.

\section{Operating Cycle}

Gitman and Zutter $(2011,604)$ defined the operating cycle as the time from beginning of the production process to collection of cash from the sale of finished product. Dechow (1994) stated that firms with longer operating cycles are expected to have larger working capital requirements for a given level of operating activity. Thus, the length of the operating cycle is an economic determinant of the volatility of working capital. Longer operating cycle lead to more estimation and error, therefore will result in lower earnings quality.

$\mathrm{H}_{2}$ Operating cycle has influence on earnings quality.

\section{Firm Size}

The large companies often offer greater collateral guarantees, and the lower risk, since they tend to be more diversified (Titman and Wessels, 1988). Large companies have larger operational activities than small firms, so the needs of large corporate debt will be higher than smaller companies. Moreover, the larger the firm size, the more transparent the disclosure of company performance to outsiders, so it will be easier for large companies to get a loan because creditors put higher trust on them. The operational sustainability in large firms will improve the financial performance so that companies do not need to manipulate their earnings (Dira and Astika, 2014).

$\mathrm{H}_{3}$ Firm size has influence on earnings quality.

\section{Sales Volatility}

Melumad and Nissim (2009) stated that revenue recognition is particularly vulnerable to manipulation. They argued that different types of transactions require different revenue recognition rules, while it is common for firms to use more than one revenue recognition method. Since management's discretion varies for each method, the relative magnitude of revenue recognized may inform about the potential for earnings management. In addition, Dechow and Dichev (2002) verified that sales volatility indicates a delicate operating environment and the greater estimations, which will result in lower earnings quality.

$\mathrm{H}_{4}$ Sales volatility has influence on earnings quality.

\section{Cash Flow Volatility}

Dechow and Dichev (2002) argued that the volatility of operations is systematically related to the propensity to make estimation errors. Theoretically, they stated that "high cash flow volatility causes low accrual quality because of large forecast errors in volatile environments, and the effect of this causal variable should not be excluded from the empirical construct." Therefore, high cash flows volatility will have 
lower quality of earnings because there will be more estimation error regarding high uncertainty.

$\mathrm{H}_{5}$ Cash flow volatility has influence on earnings quality.

\section{Losses}

Conservatism holds an important role related with losses (Šodan, 2012). Timely loss recognition increases efficiency of debt contracting and improves quality of accounting information that is useful to creditors in context of corporate governance and loan agreements. Hayn (1995) suggested that firms whose earnings are expected to fall just below the zero earnings point engage in earnings manipulations to help them cross the 'red line' for the year. In addition, managers of troubled firms that are close to a debt covenant violation have incentives to conduct income-increasing to avoid or defer the costs of a breach (Watts and Zimmerman, 1990; Sweeney, 1994). Earnings management such as income-increasing actions indicates low earnings quality.

$\mathrm{H}_{6}$ Losses have influence on earnings quality.

\section{Cost of Debt}

According to Šodan (2012), lenders should offer lower interest rates to those borrowers who have more conservative financial reporting, for example timely loss recognition. It improves debt agreement efficiency by sending a timelier signal of default risk to debtholders and by allowing them to take protective actions. Diamond (1991) in Ghosh and Moon (2010) also argued that debt holders should offer lower borrowing costs for demanding higher quality information, especially earnings, to assess the creditworthiness of borrowers. This implies the negative relationship between cost of debt and earnings quality.

$\mathrm{H}_{7}$ Cost of debt has influence on earnings quality.

\section{Z-score}

Altman (1968) found that companies with Z-scores above 3.0 are unlikely to fail, while those with Z-scores below 1.81 are very likely to fail. Z-scores are used by banks for loan evaluation. Altman (1968) stated that "insolvency in a bankruptcy sense occurs when the total liabilities exceed a fair valuation of the firm's assets with value determined by the earning power of the assets". In addition, managers of the troubled firms that are close to a debt covenant violation and default risk have incentives to take income-increasing actions (DeAngelo et al., 1994). This means that financial distress is declining the earnings quality.

$\mathrm{H}_{8} \mathrm{Z}$-score has influence on earnings quality.

\section{RESEARCH METHODS}

The statistics population of this research is non-financial companies listed in Indonesia Stock Exchange (IDX) from 2007 to 2013. This research uses purposive sampling method to obtain the sample that meets the criteria in Table 1. For the purpose of homogeneity of the sample, companies should not be in service sector (sector 6-9 in IDX Fact Book). Furthermore, excluding service sector is needed in order to consistently measure the operating cycle of companies, which require the information about cost of goods sold and inventory.

The type of data used in this research is secondary data, which obtained from publicly available information. Data needed in this research is provided in financial statement of listed companies from 2007 to 2013. Data are obtained from the observed company's website and Indonesia Stock Exchange website (IDX): http://www.idx.co.id. 
Table 1 Sample Selection Procedure

\begin{tabular}{lcc}
\hline \multicolumn{1}{c}{ Criteria Description } & $\begin{array}{c}\text { Number of } \\
\text { Companies }\end{array}$ & Number of Data \\
\hline $\begin{array}{l}\text { Non-financial companies excluding service sector that } \\
\text { consistently listed in Indonesia Stock Exchange from } 2007\end{array}$ & 145 & 435 \\
to 2013 \\
$\begin{array}{l}\text { Companies' financial statement closing date is not } \\
\text { December } 31 \text { from } 2007 \text { to } 2013 \\
\text { Companies' reporting currency is not in Rupiah from 2007 to }\end{array}$ \\
$\begin{array}{l}2013 \\
\text { Companies that are not reporting the variables needed from } \\
2010 \text { to 2013 }\end{array}$ \\
\begin{tabular}{l} 
Total companies that are used as the sample \\
\hline
\end{tabular}
\end{tabular}

Residuals are measured as a reverse proxy of earnings quality. In measuring earnings quality as the dependent variable, the Kothari et al. (2005) model is used. This model uses discretionary accruals. Following the definition of earnings developed by Dechow (1994), total accruals (TAC) for firm $i$ in year $t$ are calculated as follow:

$$
\mathrm{TAC}_{\mathrm{i}, \mathrm{t}}=\mathrm{NI}_{\mathrm{i}, \mathrm{t}}-\mathrm{OCF}_{\mathrm{i}, \mathrm{t}}
$$

Where:

$\mathrm{TAC}_{\mathrm{i}, \mathrm{t}}=$ total accruals in year $\mathrm{t}$ for firm $\mathrm{i}$

$\mathrm{Nl}_{i, \mathrm{t}} \quad=$ net income in year $\mathrm{t}$ for firm $\mathrm{i}$

OCF $_{i, t}=$ operating cash flow in year $t$ for firm $\mathrm{i}$

Discretionary accruals are obtained by

excluding non-discretionary accruals from total accruals. Kothari et al. (2005) developed a following model:

$\frac{\mathrm{TAC}_{i t}}{\mathrm{TA}_{\mathrm{it}-1}}=\beta_{0}\left(\frac{1}{\mathrm{TA}_{\mathrm{i}, \mathrm{t}-1}}\right)+\beta_{1}\left(\frac{\Delta \mathrm{SALES}_{\mathrm{i}, \mathrm{t}}-\Delta \mathrm{AR}_{\mathrm{i}, \mathrm{t}}}{\mathrm{TA} \mathrm{A}_{\mathrm{i},-1}}\right)+\beta_{2}\left(\frac{\mathrm{PPE}_{\mathrm{i}, \mathrm{t}}}{\mathrm{TA}_{\mathrm{i}, \mathrm{t}-1}}\right)+\beta_{3}\left(\mathrm{ROA}_{\mathrm{i}, \mathrm{t}}\right)+\varepsilon_{\mathrm{i}, \mathrm{t}}$

Where:

$\mathrm{TAC}_{\mathrm{i}, \mathrm{t}}=$ total accruals in year $\mathrm{t}$ for firm

$\mathrm{TA}_{\mathrm{i}, \mathrm{t}-\mathrm{1}}=$ total assets in year $\mathrm{t}-1$ for firm i

$\triangle$ SALES $_{i, t} \quad=$ revenues in year $t$ less revenues in year t-1 for firm i
$\Delta \mathrm{AR}_{\mathrm{i}, \mathrm{t}} \quad=$ accounts receivable in year $\mathrm{t}$ less accounts receivable in year t-1 for firm i

$P P E_{i, t} \quad=$ gross property, plant, and equipment in year $t$ for firm $i$

$\mathrm{ROA}_{\mathrm{i}, \mathrm{t}} \quad=$ return on assets in year $t$ for firm i, computed by dividing net income in year $t$ by total assets in year $t$

$\beta_{0}, \beta_{1}, \beta_{2}, \beta_{3}=$ coefficients

$\varepsilon_{i, t}=$ error term

The discretionary accruals are obtained as residuals from the model above. Since earnings quality is inversely related to discretionary accruals, the higher the residuals, the lower the earnings quality (Ghosh and Moon, 2010).

Debt (DEBT) is computed by dividing total debt (both short term and long term) by total assets (Weygandt et al. 2011, 675; Valipour and Moradbeygi, 2011). Debt to total asset uses ratio scale.

$$
\text { DEBT }=\frac{\text { Long Term Debt }+ \text { Short Term Debt }}{\text { Total Assets }}
$$

Low debt financing (LOWDEBT) is debt ratio between scopes of 0 to 50 percent, measured using dummy variable. The value of 0 means the company has high debt ratio (greater 
than 0.5 ), while the value of 1 means that it has low debt ratio (range from 0 to 0.5 ).

High debt financing (HIGHDEBT) is debt ratio greater than 50 percent, measured using dummy variable. The value of 0 means the company has low debt ratio (range from 0 to 0.5 ), while the value of 1 means that it has high debt ratio (greater than 0.5 ).

Operating cycle $(\mathrm{OC})$ is measured as $\log$ of the sum of days of accounts receivable and days of inventory outstanding (Valipour and Moradbeygi, 2011). Operating cycle uses ratio scale.

$$
\begin{gathered}
\mathrm{OC}=\log (\text { Days of Accounts Receivable }+ \text { Days } \\
\text { of Inventory Outstanding })
\end{gathered}
$$

Where:

Days of Accounts Receivable $=360$ /

(Sales / Average Accounts Receivables)

Days of Inventory Outstanding $=360$ I

(Cost of Goods Sold / Average Inventory)

Firm size (SIZE) is the logarithmic formulation of the average of the beginning and ending total assets (Valipour and Moradbeygi, 2011). Firm size uses ratio scale.

$$
\text { SIZE }=\log \left(\frac{\text { Beginning Total Assets }+ \text { Ending Total Assets }}{2}\right)
$$

Sales volatility $\left(\mathrm{SALES}_{\sigma}\right)$ is the standard deviation of sales scaled by average total assets (Valipour and Moradbeygi, 2011). Sales volatility uses ratio scale.

$$
\text { SALES }_{\sigma}=\frac{\text { Standard Deviation of Sales }}{\text { Average Total Assets }}
$$

Where:

Standard Deviation of Sales $=\sqrt{\frac{\sum_{i=1}^{3}\left(\text { Salest }_{t} \overline{\text { Sales }}\right)^{2}}{n-1}}$ from 2011 to 2013

Cash flow volatility $\left(\mathrm{OCF}_{\sigma}\right)$ is the standard deviation of operating cash flow scaled by average total assets (Valipour and Moradbeygi, 2011). Sales volatility uses ratio scale.

$$
\mathrm{OCF}_{\sigma}=\frac{\text { Standard Deviation of OCF }}{\text { Average Total Assets }}
$$

Where:

Standard Deviation of OCF $=\sqrt{\frac{\sum_{i=1}^{3}\left(\mathrm{OCF}_{\mathrm{t}}-\overline{\mathrm{OCF}}\right)^{2}}{n-1}}$ from 2011 to 2013

Losses (LOSSES) are proportion of firm-years with negative earnings from year $t-4$ to year t (Valipour and Moradbeygi, 2011). Losses use ratio scale.

$$
\text { LOSSES }=\frac{\text { Frequency of negative earnings from } t-4 \text { to } t}{5}
$$

Where:

$\mathrm{t}=$ year 2011, 2012, and 2013

Cost of debt (COD) is interest expense deflated by average total debt (Valipour and Moradbeygi, 2011). Finance costs are used as a proxy of interest expense (Kieso et al. 2011, 147-148). Cost of debt uses ratio scale.

$$
\mathrm{COD}=\frac{\text { Interest Expense }}{\text { Average Total Debt }}
$$

Where:

Average Total Debt = (Beginning Total Debt + Ending Total Debt) / 2

Z-score (Z-SCORE) is measured as a proxy of financial distress with the following formula (Valipour and Moradbeygi, 2011):

Z-SCORE $=1.2\left(\frac{\mathrm{WC}}{\mathrm{TA}}\right)+1.4\left(\frac{\mathrm{RE}}{\mathrm{TA}}\right)+3.3\left(\frac{\mathrm{EBIT}}{\mathrm{TA}}\right)+0.6\left(\frac{\mathrm{MVE}}{\mathrm{TL}}\right)+\left(\frac{\text { Sales }}{\mathrm{TA}}\right)$

Where:

WC = Working Capital $=$ Current Assets Current Liabilities

$\mathrm{TA} \quad=$ Total Assets

$\mathrm{RE} \quad=$ Retained Earnings

EBIT = Earnings before Interest and Taxes

MVE = Market Value of Equity $=$ Market Price per Share $\times$ Outstanding Shares

$\mathrm{TL} \quad=$ Total Liabilities

There will be three regression models to test the hypotheses as follows: 


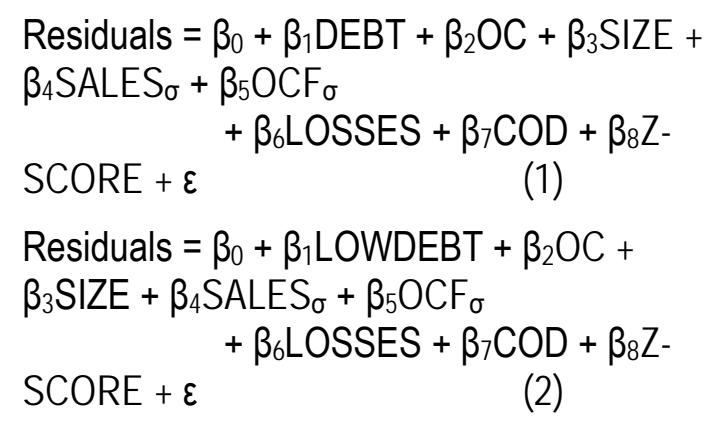

$$
\begin{aligned}
& \text { Residuals }=\beta_{0}+\beta_{1} \text { HIGHDEBT }+\beta_{2} \mathrm{OC}+ \\
& \beta_{3} \text { SIZE }+\beta_{4} \text { SALES }_{\sigma}+\beta_{5} \text { OCF } \\
& \multicolumn{1}{c}{+\beta_{6} \text { LOSSES }+\beta_{7} \text { COD }+\beta_{8} Z-} \\
& \text { SCORE }+\varepsilon \quad \text { (3) }
\end{aligned}
$$

\section{RESEARCH RESULTS AND DISCUSSIONS \\ The result of descriptive statistics tests are shown in the tables below:}

Table 2 Descriptive Statistics

\begin{tabular}{lrrrr}
\hline \multicolumn{1}{c}{ Variable } & \multicolumn{1}{c}{ Minimum } & \multicolumn{1}{c}{ Maximum } & \multicolumn{1}{c}{ Mean } & \multicolumn{1}{c}{$\begin{array}{c}\text { Std. } \\
\text { Deviation }\end{array}$} \\
\hline DEBT & 0.000417 & 0.915571 & 0.29044187 & 0.191213509 \\
LOWDEBT & 0 & 1 & 0.86 & 0.351 \\
HIGHDEBT & 0 & 1 & 0.14 & 0.351 \\
OC & 1.686593 & 2.756778 & 2.11442188 & 0.206392361 \\
SIZE & 10.637239 & 14.296959 & 12.22087047 & 0.710740998 \\
SALES $_{\sigma}$ & 0.009145 & 0.782340 & 0.17510723 & 0.142965741 \\
OCF $_{\sigma}$ & 0.003407 & 0.222615 & 0.05247470 & 0.038428800 \\
LOSSES $_{\text {COD }}$ & 0.000000 & 1.000000 & 0.13306122 & 0.255610841 \\
Z-SCORE & 0.004274 & 0.479522 & 0.09003436 & 0.058713219 \\
Residuals & -3.811858 & 19.702951 & 3.68800948 & 4.018897801 \\
\hline & -0.26077 & 0.24745 & 0.0001601 & 0.08182333 \\
\hline
\end{tabular}

Table 3 LOWDEBT Frequency Table

\begin{tabular}{lrrrr}
\hline \multicolumn{1}{c}{ Variable } & Frequency & \multicolumn{1}{c}{ Percent } & Valid Percent & $\begin{array}{c}\text { Cumulative } \\
\text { Percent }\end{array}$ \\
\hline HIGHDEBT & 35 & 14.3 & 14.3 & 14.3 \\
LOWDEBT & 210 & 85.7 & 85.7 & 100.0 \\
Total & 245 & 100.0 & 100.0 & \\
\hline
\end{tabular}

Table 4 HIGHDEBT Frequency Table

\begin{tabular}{lrrrr}
\hline \multicolumn{1}{c}{ Variable } & Frequency & Percent & Valid Percent & $\begin{array}{c}\text { Cumulative } \\
\text { Percent }\end{array}$ \\
\hline LOWDEBT & 210 & 85.7 & 85.7 & 85.7 \\
HIGHDEBT & 35 & 14.3 & 14.3 & 100.0 \\
Total & 245 & 100.0 & 100.0 & \\
\hline
\end{tabular}

The t-test result of model 1, 2 and 3 are shown in the tables below: 
Table $5 \mathrm{t}$ Test Result Model 1

\begin{tabular}{lrr}
\hline \multicolumn{1}{c}{ Variable } & Coefficient & \multicolumn{1}{c}{ Significance } \\
\hline DEBT & 0.134 & 0.002 \\
OC & 0.011 & 0.704 \\
SIZE & -0.019 & 0.039 \\
SALES $_{\sigma}$ & 0.005 & 0.908 \\
OCF $_{\sigma}$ & -0.240 & 0.091 \\
LOSSES $_{\text {COD }}$ & -0.067 & 0.007 \\
Z-SCORE & 0.061 & 0.517 \\
\multicolumn{2}{c}{ Adjusted R2 $0.043, \mathrm{~F}_{8.236} 2.381$, Sig. 0.017}
\end{tabular}

Table 6 t Test Result Model 2

\begin{tabular}{lrr}
\hline \multicolumn{1}{c}{ Variable } & \multicolumn{1}{c}{ Coefficient } & \multicolumn{1}{c}{ Significance } \\
\hline DEBT & -0.054 & 0.002 \\
OC & 0.016 & 0.591 \\
SIZE & -0.012 & 0.175 \\
SALES $_{\sigma}$ & 0.025 & 0.553 \\
OCF $_{\sigma}$ & -0.174 & 0.209 \\
LOSSES $_{\text {COD }}$ & -0.069 & 0.007 \\
Z-SCORE & -0.007 & 0.935 \\
\multicolumn{2}{c}{ Adjusted R ${ }^{2} 0.042, F_{8.236} 2.322$, Sig. 0.020}
\end{tabular}

Table $7 \mathrm{t}$ Test Result Model 3

\begin{tabular}{lrr}
\hline \multicolumn{1}{c}{ Variable } & \multicolumn{1}{c}{ Coefficient } & \multicolumn{1}{c}{ Significance } \\
\hline DEBT & 0.054 & 0.002 \\
OC & 0.016 & 0.591 \\
SIZE $_{\text {SALES }_{\sigma}}$ & -0.012 & 0.175 \\
OCF $_{\sigma}$ & 0.025 & 0.553 \\
LOSSES $_{\text {COD }}$ & -0.174 & 0.209 \\
Z-SCORE & -0.069 & 0.007 \\
\multicolumn{2}{c}{ Adjusted R } & 0.042, F $_{8.236} 2.322$, Sig. 0.020
\end{tabular}

In model 1, debt has significance level of 0.002 , which is below a (0.05). Thus, $\mathrm{H}_{\mathrm{a} 1}$ is accepted, means that debt has influence on earnings quality. This result is consistent with Ghosh and Moon (2010), and Valipour and Moradbeygi (2011), but is not consistent with the research from Sutopo (2012) with control variables.
The result shows that in model 2 , low debt has significance level of 0.002 , which is below a (0.05), means that low debt has influence on earnings quality. In addition, low debt has coefficient value of -0.054 , means that each increase of one unit of low debt as the independent variable will decrease the Residuals as the dependent variable for 0.054 , assuming all remaining independent variables 
are fixed. Since earnings quality is inversely related with the Residuals, the low debt has positive influence on earnings quality. Therefore, $\mathrm{H}_{1 \mathrm{a}}$ is accepted. This result is consistent with the researches of Ghosh and Moon (2010), Valipour and Moradbeygi (2011), and Sutopo (2012) without control variables.

The result shows that in model 3 , high debt has significance level of 0.002 , which is below a (0.05), means that high debt has influence on earnings quality. In addition, high debt has coefficient value of 0.054 , means that each increase of one unit of high debt as the independent variable will increase the Residuals as the dependent variable for 0.054 , assuming all remaining independent variables are fixed. Since earnings quality is inversely related with the Residuals, the high debt has negative influence on earnings quality. Thus, $\mathrm{H}_{1 b}$ is accepted. This result is consistent with the researches of Ghosh and Moon (2010), Valipour and Moradbeygi (2011), and Sutopo (2012) without control variables.

Operating cycle variable has significance level of 0.704 in model 1 and 0.591 in both model 2 and 3 , which are below a (0.05). Thus, $\mathrm{H}_{\mathrm{a} 2}$ is rejected. It means operating cycle has no influence on earnings quality in all regression models. This result is consistent with Pagalung and Sudibdyo (2012), but is not consistent with Dechow and Dichev (2002), Francis et al. (2005), Ghosh and Moon (2010), as well as Valipour and Moradbeygi (2011).

Size variable has significance level of 0.039 in model 1 , which is below a (0.05). It means that size has influence on earnings quality when it is regressed with debt as a whole. This result is consistent with Dechow and Dichev (2002), Francis et al. (2005), Moses (1987) in Dechow et al. (2010), Ghosh and Moon (2010), Valipour and Moradbeygi (2011), and Sutopo (2012).

However, in model 2 and 3 , size variable has significance level of 0.175 , which is above a (0.05). It means that size has no influence on earnings quality when it is regressed with both low and high debt. This result is consistent with Pagalung and Sudibdyo (2012).

Sales volatility variable has significance level of 0.908 in model 1 and 0.553 in both model 2 and 3 , which are above a (0.05). Thus, $\mathrm{H}_{a 4}$ is rejected. It means sales volatility has no influence on earnings quality in all regression models. This result is not consistent with Dechow and Dichev (2002), Francis et al. (2005), Ghosh and Moon (2010), Valipour and Moradbeygi (2011), Chang et al. (2012), as well as Pagalung and Sudibdyo (2012).

Cash flow volatility variable has significance level of 0.091 in model 1 and 0.209 in both model 2 and 3 , which are above a (0.05). Thus, $\mathrm{H}_{\mathrm{a} 5}$ is rejected. It means cash flow volatility has no influence on earnings quality in all regression models. This result is not consistent with Dechow (1994), Dechow et al. (1998), Dechow and Dichev (2002), Francis et al. (2005), as well as Ghosh and Moon (2010).

Losses variable has significance level of 0.007 in all regression models, which is below a (0.05). Thus, $\mathrm{H}_{a 6}$ is accepted. It means losses have influence on earnings quality in all regression models. This result is consistent with Hayn (1995), Dechow and Dichev (2002).

Cost of debt variable has significance level of 0.517 in model 1 and 0.935 in both model 2 and 3 , which are above a (0.05). Thus, $\mathrm{H}_{a 7}$ is rejected. It means cost of debt has no influence on earnings quality in all regression models. This result is consistent with Ghosh and Moon (2010), but is not consistent with Francis et al. (2005), Liu et al. (2010) in Valipour and Moradbeygi (2011), and Šodan (2012).

Z-score variable has significance level of 0.627 in model 1 and 0.198 in both model 2 and 3 , which are above a (0.05). Thus, $H_{a 7}$ is rejected. It means Z-score has no influence on earnings quality in all regression models. This result is not consistent with Ghosh and Moon (2010), Valipour and Moradbeygi (2011), as well as Kim et al. (2011) in Valipour and Moradbeygi (2011). 


\section{CONCLUSION}

Based on the hypothesis testing, debt and losses have influence on earnings quality. Directionally, low debt has positive influence and high debt has negative influence on earnings quality. Firm size has influence on earnings quality when it is regressed with whole debt. Meanwhile, it has no influence when it is regressed with low and high debt. Sales volatility, cash flows volatility, cost of debt and Z- score have no influence on earnings quality. This research period is relatively short, which is only three years and the research sample is focused only on listed non-financial companies excluding service sector, so the result cannot be generalized for the overall industries. Some recommendations that can be used for the future research, which are lengthen the period research to get more accurate result and enlarge the research population.

\section{REFERENCES:}

Altman, Edward I. 1968. Financial Ratios, Discriminant Analysis and the Prediction of Corporate Bankruptcy. The Journal of Finance vol. 23 no. 4, pg. 589-609.

Ball, Ray and Lakshmanan Shivakumar. 2006. The Role of Accruals in Asymmetrically Timely Gain and Loss Recognition. Journal of Accounting Research vol. 44 no.2, pg. 207-242. http://www.jstor.org/stable/3542439 (accessed December 1, 2014)

Burgstahler, David and llia D. Dichev. 1997. Earnings Management to Avoid Earnings Decreases and Losses. Journal of Accounting and Economics vol. 24, pg. 99-126.

Chang, Shen-Ho, Shaio Yan Huang, An-An Chiu, and Mei-Ting Huang. 2012. Construction of Investment Risk Measure by the Dispersion Degree of Estimation Errors of Working Capital. Journal of Applied Finance \& Banking vol. 2 no. 1, pg. 171-195.

Cheng, C.S. Agnes, Joseph Johnston, and Cathy Zishang Liu. 2013. The Supplemental Role of Operating Cash Flows in Explaining Share Returns: Effect of Various Measures of Earnings Quality. International Journal of Accounting and Information Management vol. 21 no. 1, pg. 53-71.

DeAngelo, Harry, Linda DeAngelo, and Douglas J. Skinner. 1994. Accounting Choice in Troubled Companies. Journal of Accounting and Economics vol. 17, pg. 113-143.

Dechow, Patricia M. 1994. Accounting Earnings and Cash Flows as Measures of Firm Performance: The Role of Accounting Accruals. Journal of Accounting and Economics vol. 18, pg. 3-42.

_ S. P. Kothari and Ross L. Watts. 1998. The Relation Between Earnings and Cash Flows. Journal of Accounting and Economics vol. 25, pg. 133-168.

— and Ilia D. Dichev. 2002. The Quality of Accruals and Earnings: The Role of Accrual Estimation Errors. The Accounting Review vol. 77, pg. 35-59.

—. Weili Ge, and Catherine Schrand. 2010. Understanding Earnings Quality: A Review of The Proxies, Their Determinants and Their Consequences. Journal of Accounting and Economics vol. 50, pg. 344-401.

Dichev, llia D., John R. Graham, Campbell R. Harvey, and Shiva Rajgopal. 2013. Earnings Quality: Evidence from The Field. Journal of Accounting and Economics vol. 56, pg. 1-33.

Dira, Kadek Prawisanti and Ida Bagus Putra Astika. 2014. Pengaruh Struktur Modal, Likuiditas, Pertumbuhan Laba, dan Ukuran Perusahaan pada Kualitas Laba. E-Jurnal Akuntansi Universitas Udayana 7.1, pg. 64-78.

Francis, Jennifer, Ryan LaFond, Per Olsson, and Katherine Schipper. 2005. The Market Pricing of Accruals Quality. Journal of Accounting and Economics vol. 39, pg. 295-327.

Ghosh, Aloke (Al) and Doocheol Moon. 2010. Corporate Debt Financing and Earnings Quality. Journal of Business Finance and Accounting vol. 37, pg. 538-559.

Ghozali, Imam. 2013. Aplikasi Analisis Multivariate dengan Program IBM SPSS 21, Edisi 7. Semarang: Badan Penerbit Universitas Diponegoro. 
Gitman, Lawrence J. and Chad J. Zutter. 2011. Principal of Managerial Finance, $13^{\text {th }}$ edition. Boston, MA: Pearson International.

Hair, Joseph F., William C. Black, Barry J. Babin, and Rolph E. Anderson. 2010. Multivariate Data Analysis, $7^{\text {th }}$ edition. New Jersey: Pearson Education, Inc.

Hayn, Carla. 1995. The Information Content of Losses. Journal of Accounting and Economics vol. 20, pg. 125-153.

Jensen, Michael C. and William H. Meckling. 1976. Theory of the Firm: Managerial Behaviour, Agency Cost, and Ownership Structure. Journal of Financial Economics vol. 3 no. 4, pg. 305-360.

Kamel, Hany and Said Elbanna. 2009. Assessing the Perceptions of The Quality of Reported Earnings in Egypt. Managerial Auditing Journal vol. 25 no. 1, pg. 32-52.

Kieso, Donald E., Jerry J. Weygandt, and Terry D. Warfield. 2011. Intermediate Accounting vol. 1, IFRS edition. New Jersey: John Wiley \& Sons, Inc.

Kothari, S. P., Andrew J. Leone, and Charles E. Wasley. 2005. Performance Matched Discretionary Accrual Measures. Journal of Accounting and Economics vol. 39, pg. 163-197.

Linck, James S., Jeffry Netter, and Tao Shu. 2013. Can Managers Use Discretionary Accruals to Ease Financial Constraints? Evidence from Discretionary Accruals Prior to Investment. The Accounting Review vol. 88 no. 6, pg. 2117-2143.

Mediaty. 2013. The Impact of Information Asymmetry Towards The Quality Of Accrual Earnings With Good Corporate Governance (GCG) As Moderating Variable. IOSR Journal of Economics and Finance (IOSRJEF) vol. 1, issue 4, Sep.-Oct. 2013, pg. 1-51.

Melumad, Nahum D. and Doron Nissim. 2009. Line-Item Analysis of Earnings Quality. Foundations and Trends in Accounting vol. 3 nos. 2-3, pg. 87-221.

Momenzadeh, Nahid and Mohammad Reza Abbaszadeh. 2013. Comparing the Earning Quality Methods of The Companies Accepted in Tehran Stock Exchange. Interdisciplinary Journal of Contemporary Research in Business vol. 5 no. 6, pg. 529-541.

Pagalung, Gagaring and Bambang Sudibdyo. 2012. The Determinant Factors of Earnings Quality and Economic Consequences. Ekuitas: Jurnal Ekonomi dan Keuangan vol. 16 no. 1, pg. 105-122.

Šodan, Slavko. 2012. Conditional Conservatism and the Cost of Debt: Evidence from Central and Eastern Europe. Croatian Operational and Research Review vol 3, pg 245-255.

Sutopo, Bambang. 2012. Utang dan Kualitas Laba. Jurnal Akuntansi dan Manajemen vol. 23 no. 2, pg. 79-86.

Sweeney, A. P. 1994. Debt Covenant Violations and Managers' Accounting Responses. Journal of Accounting and Economics vol. 17, pg. 281-308.

Titman, Sheridan and Roberto Wessels. 1988. The Determinant of Capital Structure Choice. The Journal of Finance vol. 43 no. 1, March 1988, pg. 1-19.

Valipour, Hashem and Medhi Moradbeygi. 2011. Corporate Debt Financing and Earnings Quality. Journal of Applied Finance and Banking vol.1 no. 3, pg. 139-157.

Watts, Ross L. and Jerold L. Zimmerman. 1990. Positive Accounting Theory: A Ten Year Perspective. University of Rochester. The Accounting Review vol. 65 no. 1, Januari 1990, pg. 131-156.

Weygandt, Jerry J., Paul D. Kimmel, and Donald E. Kieso. 2011. Financial Accounting, IFRS Edition. New Jersey: John Wiley \& Sons, Inc. 